\title{
Imperatives in Swedish medical consultations
}

\section{Lindström, Jan Krister}

John Benjamins

2017-08-15

Lindström , J K , Lindholm , C C , Norrby , C , Wide , C \& Nilsson , J 2017 , Imperatives in Swedish medical consultations . in M-L Sorjonen, L Raevaara \& E Couper-Kuhlen (eds), Imperative Turns at Talk: The Design of Directives in Action . 1 edn , vol. 30,10 , Studies in Language and Social Interaction, vol. 30 , John Benjamins , Amsterdam , pp. 299-324 . https://doi.org/10.1075/slsi.3

http://hdl.handle.net/10138/232250

https://doi.org/10.1075/slsi.30.10lin

other

acceptedVersion

Downloaded from Helda, University of Helsinki institutional repository.

This is an electronic reprint of the original article.

This reprint may differ from the original in pagination and typographic detail.

Please cite the original version. 


\title{
Imperatives in Swedish medical consultations
}

\author{
Jan Lindström \\ University of Helsinki \\ Camilla Lindholm \\ University of Helsinki \\ Catrin Norrby \\ Stockholm University \\ Camilla Wide \\ University of Turku \\ Jenny Nilsson \\ Swedish Institute for Language and Folklore
}

Abstract

This chapter investigates the use of imperative-formatted directives in Swedish medical consultations. The specific focus of the chapter is the division of labor between straight, non-modulated imperative turns and imperative turns which are modulated with a discourse particle or some other verbal mitigating device. The results show that non-modulated imperative turns are embedded in diagnostic work, nominating subsequent actions in a series. Orientations to projected trajectories of action and the other participant's expectations are clearly present when modulated imperative turns are produced; they are also frequent in the opening and closing routines of the consultations. Thus, there is a link between 
routinized and projectable actions and the use of imperatives with a pragmatic modulating element.

Keywords

Swedish, Finland Swedish, pluricentric languages, non-modulated imperative turns, modulated imperative turns, routine actions, series of actions, diagnostic activity, discourse particles, medical consultations

\section{Introduction}

In this chapter we report findings from an analysis of directives implemented by using the imperative mood in Swedish medical consultations. While the use of imperatives and straight, non-modulated directives may be restricted in contemporary Swedish communicative culture in general (cf. Hellberg 1990:35), our study shows that the medical consultation is a communicative activity type in which imperatives occur regularly. The imperatives are studied with regard to their embeddedness in the activities during the medical consultation. The key question is to investigate what warrants the use of the imperative in specific activities and sequences of actions underway. We pay special attention to the interplay between verbal and embodied actions during the physical examination, and on the division of labor between non-modulated imperative turns and 
imperative turns which are modulated with a discourse particle or some other verbal device. ${ }^{1}$ In addition, the analysis aims to account for variation detected in the use of imperatives in the two datasets we base our study on, one consisting of consultations recorded in Sweden, one of consultations recorded in Finland.

The medical consultation is a type of activity, which takes place in an institutional setting. As pointed out by Drew and Heritage (1992:47), institutional interactions are characteristically asymmetrical and participants have complementary roles. In such contexts, the professional often has the primary opportunity to produce initiatives, whereas the layperson's contributions may be limited to responsive moves, like the following of instructions (id. 49). Likewise, there are asymmetries in the epistemic domain; the professional (the doctor) has superior knowledge and authority on biomedical matters while the layperson (the patient) has primary access to his or her psychophysiological experience (cf. Stivers, Mondada, and Steensig 2011).

Swedish has a designated morphological form and sentence type for imperatives. Although the imperative mood in Swedish is prototypically used to constitute a directive action, directives can also be implemented through a range of other grammatical formats, such as polar questions. On

\footnotetext{
${ }^{1}$ We focus on modification of the imperative turn, rather than that of the imperative verb, in order to investigate whether or not the directive action is modulated with certain conventional elements, such as restricting adverbs or discourse particles.
} 
the other hand, imperatives may express other kinds of actions than directives, such as polite wishes like sov gott 'sleep tight' (see Hellberg 1990; Teleman, Hellberg, and Andersson 1999:705, 720, 723). The Swedish imperative has no inflectional endings; the imperative is identical to the infinitive (vänta 'wait') or the verb stem of the infinitive (ring/a 'ring, call'), depending on the conjugation class of the verb. As regards syntax, the imperative verb stands in the first constituent position and the clause does not usually include the second person subject: Ring mig i morgon 'Call me tomorrow'. Imperatives can be modified in several ways in Swedish (cf. Rothstein 2010): with polite formulae ( Var så god och sitt 'Be so good and sit'), appealing forms of address (Gör det snälla 'Do so please'), restricting adverbs (Sätt den bara där nånstans 'Place it simply there somewhere') and certain verb combinations ( $\underline{\text { Ta och }}$ ligg ner '(Why don't you) lie down', lit. 'take and lie down').

Directives and imperatives have not been dealt with to any greater extent in research on Swedish. Different ways of communicating directive actions and modifications of the deontic meaning of the imperative have been discussed by Hellberg (1990). He notes that directives can be framed as commands, appeals, offers and advice, depending on the means of modification. This perspective has been discussed in more detail in a chapter on "directive main clauses" (i.e. mainly imperative-formatted sentences) in Teleman et al. 1999. However, none of these accounts are based on empirical evidence from conversational interaction. A clearly pronounced 
conversation analytic (CA) angle is taken in Anna Lindström's (2005) study of directive actions in the Swedish home help service, which presents an analysis of how senior citizens request assistance in their home environment. The study compares requests formatted as imperatives and syntactic questions. The conclusion is that by formulating a request as an imperative, the speaker claims that she is entitled to ask for assistance. With the question format, entitlement is less obvious.

In the following we first describe our data and methods in section 2. In section 3 we present an overview of the types of imperative formats, and their overall frequency and distribution across the major phases of the medical consultation. In section 4 we give an account of non-modulated imperative turns, mainly found during the physical examination, and in section 5 we discuss imperative turns modulated by discourse particles and other mitigating elements. Section 6 gives a summary and conclusion of the results.

\section{Data and method}

Our data are drawn from the two national varieties of Swedish, Finland Swedish and Sweden Swedish. Swedish is a so-called pluricentric language - a language with more than one national center (Clyne 1992). It is the main language of Sweden where the vast majority of the population of about 9.7 
million (Statistics Sweden 2015) has Swedish as their first language. In Finland, Swedish is the first language of $5.3 \%$ of the population of 5.5 million (Statistics Finland 2015). By far, most inquiry into pluricentric languages has concerned structural differences between varieties, and Swedish is no exception to this trend. Typical features of Finland-Swedish pronunciation, vocabulary and syntax are well documented in the literature (see e.g. Reuter 1992; Wide and Lyngfelt 2009) whereas pragmatic and interactional aspects have only been the focus of a few small-scale studies (see Saari 1995). While the overall interactional practices are similar across the two varieties there is also evidence of subtle differences in pragmatic routines and ways of formulating verbal actions (see Norrby et al. 2015a, and Norrby et al. $2015 \mathrm{~b}$ on address practices in medical consultations and in service encounters respectively). ${ }^{2}$

More specifically, the data for this study are sourced from two corpora of video-recorded medical consultations in Swedish, collected in Finland and Sweden respectively. The Finland-Swedish corpus INK (Interaktion $i$ en institutionell kontext, 'Interaction in an institutional context') was collected in general and rheumatological practices during 1996-2000. The data consist of twenty consultations between five physicians and 20 patients who suffer from fibromyalgia and other types of

2 The bi-national research programme Interaction and Variaton in Pluricentric Languages Communicative Patterns of Sweden Swedish and Finland Swedish funded by Riksbankens Jubileumsfond (Grant ID: M12-0137:1) aims at providing a comprehensive comparison of communicative patterns in the two national varieties of Swedish. 
chronic, widespread pain (Lindholm 2003). The size of the corpus is approximately 13 hours, and the length of the consultations varies from 22 to 52 minutes with an average length of 38 minutes. Of the five doctors, three were male and two female. All patients were female.

The Sweden-Swedish corpus LOP (Läkare- och patientsamtal, 'Conversations between doctors and patients') was collected at four hospitals and medical clinics in central Sweden during 1988-1992. It includes 15 medical consultations between nine doctors and 15 patients who suffer from rheumatism (Melander Marttala 1995). The total size of the corpus is 7 hours with consultations ranging from 10 to 50 minutes with an average length of 28 minutes. There were 11 female and 4 male patients. Of the doctors, four were female and five male.

Both corpora include initial as well as follow-up consultations, and are comparable in terms of the type of ailment the patients are seeking treatment for. As such, these two corpora constitute a unique source for comparing the two national varieties of Swedish in the medical domain. All participants consented to be recorded and the data were anonymized. The transcripts follow common CA notation principles, and a multimodal notation is used to capture embodied actions whenever relevant for the analysis.

Our methodological approach is rooted in the traditions of conversation analysis and interactional linguistics. Based on the 20 hours of recordings, we collected a total of 123 directive action sequences, which 
involved the use of an imperative form. We analysed the videotaped data paying attention to the trajectories of multimodal communication: the coordination of linguistic and embodied communicative means, the sequential organization of interaction and the situatedness of actions in the distinct activity phases of medical consultations. The following section gives an account of the quantitative distribution of imperative turn formats in the data.

\section{Overview of imperatives in the data}

With a total of 123 occurrences in the data, it is fair to say that the medical consultation is an activity type in which imperatives occur with some frequency. Table 1 gives an overview of the imperative forms found in the consultations recorded in Sweden (the corpus LOP) and Finland (the corpus INK), henceforth referred to as S-SWE and F-SWE respectively. It shows the overall number of imperative verb tokens in the two datasets, as well as counts for modulated and non-modulated imperatives, and imperatives appearing in verb combinations or fixed expressions. We have chosen to focus only on the doctors' imperative turns, as the patients use imperatives rarely and in well-limited contexts. 


\begin{tabular}{|l|l|l|l|}
\hline & S-SWE & F-SWE & Total $^{3}$ \\
\hline $\begin{array}{l}\text { Non-modulated } \\
\text { imperatives }\end{array}$ & 50 & 28 & 78 \\
\hline Modulated w particles & 6 & 25 & 31 \\
\hline $\begin{array}{l}\text { Modulated w polite } \\
\text { formulae }\end{array}$ & 8 & 6 & 14 \\
\hline $\begin{array}{l}\text { Imperative verb } \\
\text { combinations }\end{array}$ & 3 & 3 & 6 \\
\hline $\begin{array}{l}\text { Fixed imperative } \\
\text { expressions }\end{array}$ & 1 & 8 & 9 \\
\hline Imperatives total & $\mathbf{6 3}$ & $\mathbf{6 0}$ & $\mathbf{1 2 3}$ \\
\hline
\end{tabular}

Table 1. Occurrence of imperatives in Swedish medical consultations from Sweden (S-SWE, 7 hrs) and Finland (F-SWE, 13 hrs); doctors' turns.

We note that overall the two corpora contain almost the same number of imperative verb forms, but they are clearly more frequent in the Swedish corpus, since it is approximately only half the size of the corpus from Finland.

There are 66 different types of imperative verbs in the data so there are some verbs which recur. The following verbs have at least four occurrences in each corpus: andas 'breath', berätta 'tell', försök 'try', håll 'hold', kom 'come', lyft 'lift', sitt 'sit', sätt 'put', sätt dig 'sit down', ta 'take', ta av 'take off', vänta 'wait'. Most of these verbs have to do either

\footnotetext{
${ }^{3}$ The occurrences of the subcategories amount to more than 123 in total. This is because the subcategorizations (modulated, fixed) split up the general category "imperatives" in different ways; for example, some of the fixed imperative expressions also contain a modulating element.
} 
with contingencies of different phases of the consultation (e.g. taking a seat during the opening), or with the examination of the patient (e.g. breathing during the examination with a stethoscope).

A more pronounced difference between the corpora can be found in the distribution of non-modulated imperatives, which occur with much greater frequency in the data from Sweden $(50 / 63,79 \%$ in S-SWE compared to $28 / 60,47 \%$ in F-SWE). The difference is matched by a greater use of particle modulation in the data from Finland (e.g. Sätt den $\underline{\text { bara }}$ där nånstans 'Just place it there somewhere'); 25/60 (42\%) of all the imperatives in F-SWE are modulated in this way, whereas this is the case for only 6/63 (10\%) imperatives in S-SWE. Modifications with polite formulae or verb combinations are generally few, but they are used in the context of certain routines: in asking the patient to take a seat, to lie down for an examination, or to get dressed after an examination. It is also worth noting that there are some fixed imperative expressions, most of them consisting of the phrase vänta nu 'wait (now)' which indexes a halt in the flow of thought or conversation (cf. Keevallik on Estonian 2003, this volume). We will return to modulated imperative turns in section 5 as there are some intriguing points about their usage and differences between the corpora.

It is hardly surprising that doctors make much greater use of imperative forms given their professional role and institutional right/obligation to instruct patients and advance the agenda of the 
consultation (cf. Mishler 1984). The few imperative turns used by patients are mostly connected to responses to suggestions made by the doctor, typically with the formulaic phrase gör det 'do that [by all means]'.

Medical consultations can be divided into relatively distinct phases, characterized by different activities (see Byrne and Long 1976, also Heritage and Maynard 2006, for an account of the internal structural organization of the medical consultation and division into six phases; also Linell 2011:205). For our purposes here a rough categorization of the communicative activity into three phases will suffice (cf. Linell 2009:205): opening (welcoming routines and initiation of the anamnesis), verbal and physical examination (the core activity), and closing (discussion of treatment, next appointments and leave-taking). ${ }^{4}$ Table 2 shows the distribution of imperatives across these three major activity phases.

\begin{tabular}{|l|l|l|l|}
\hline Activity phase: & S-SWE & F-SWE & Total \\
\hline Opening & 2 & 20 & 22 \\
\hline $\begin{array}{l}\text { Verbal and physical } \\
\text { examination }\end{array}$ & 47 & 21 & 68 \\
\hline Closing & 14 & 19 & 33 \\
\hline Total & $\mathbf{6 3}$ & $\mathbf{6 0}$ & $\mathbf{1 2 3}$ \\
\hline
\end{tabular}

Table 2. Distribution of imperative tokens across the major phases of medical consultations from Sweden (S-SWE, $7 \mathrm{hrs)} \mathrm{and} \mathrm{Finland} \mathrm{(F-SWE,} 13 \mathrm{hrs);} \mathrm{doctors'}$

\footnotetext{
${ }^{4}$ Discussion of treatment is very often intertwined with other closing activities, such as discussion of dates for the next visit and leave-takings. We have thus chosen to use the rather rough but still illuminating division into three phases: a distinct core activity (examination) which is surrounded by preliminary (opening) and concluding (closing) activities.
} 
turns.

As Table 2 shows, the distribution of imperatives differs between the two datasets. In the data from Finland, imperatives are evenly distributed across the three phases, whereas in the data from Sweden imperatives appear predominantly during the verbal/physical examination, especially when the doctor instructs the patient to do different kinds of body movements during diagnostic work. In the following section we focus on this activity context where many of the non-modulated imperative turns occur.

\section{Non-modulated imperative turns: the physical examination}

Our analysis of imperatives during the examination phase revealed a recurring pattern: the directive actions in the form of an imperative were preceded by directive actions expressed with other types of grammatical formats. In other words, the imperatives did not initiate activities with sequences of directive actions, but were embedded in an ongoing activity sequence (see Rossi this volume). To illustrate this pattern, we begin by considering extract (1), from the data from Sweden; in line 1, the doctor initiates a diagnostic activity by asking the patient to sit down on the examination table ("the bench") for an examination of her knee, using a declarative with a modal verb (kan 'can'). When the patient is seated on the 
examination table, the doctor places himself in front of her and, using a nonmodulated imperative, requests the next action: the patient is to dangle her legs (1. 4). In this and the following extracts in this section, lines containing directive actions irrespective of grammatical format are arrowed; the turn constructional units (TCUs) containing an imperative are shaded with grey and the imperative verbs are additionally bolded.

(1) [S-SWE:LOP:3]

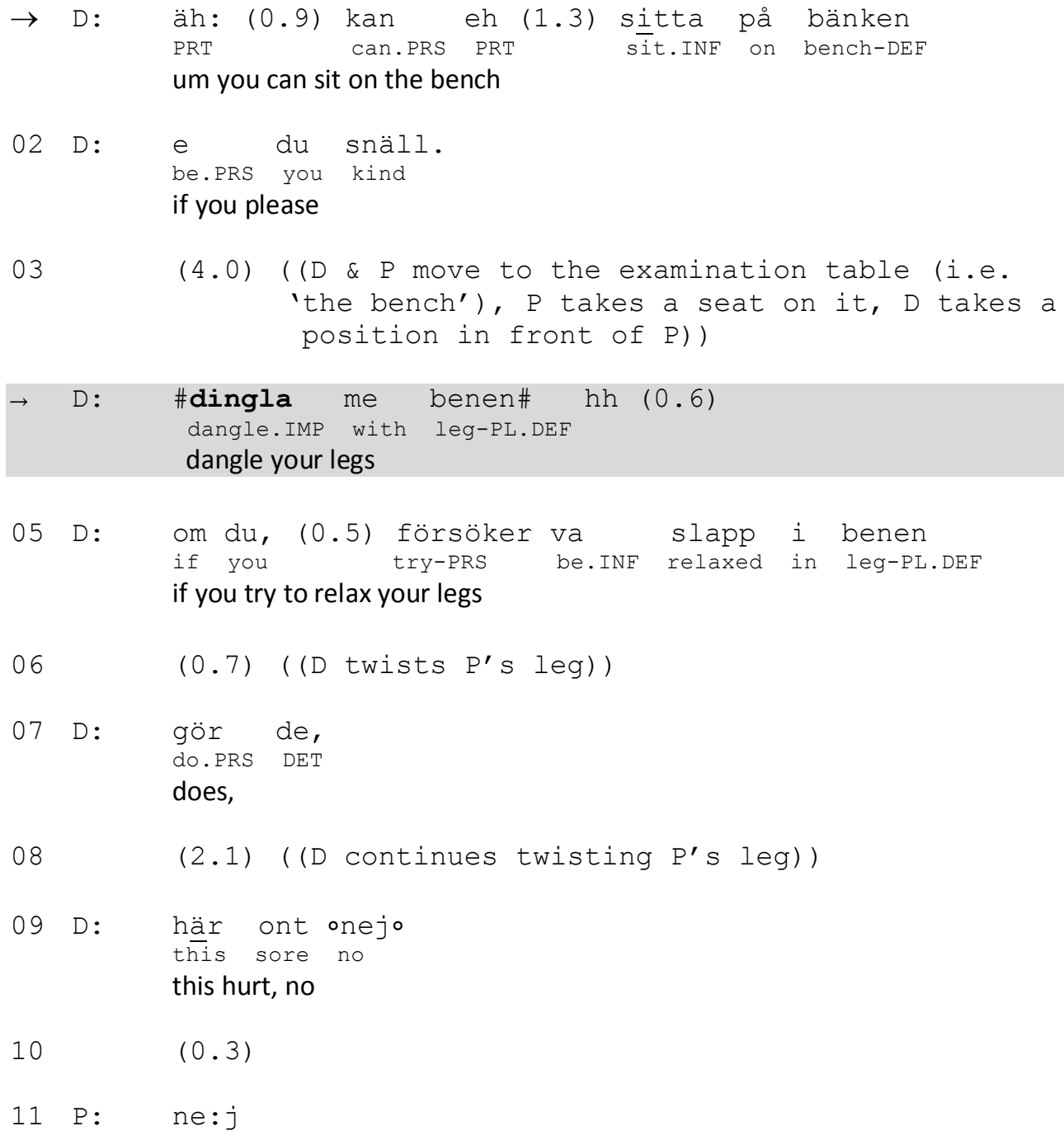


The following extract (2), taken from the Finland Swedish data set, provides an example in which the imperative turn is embedded in on-going diagnostic work.

\section{(2) [F-SWE:INK:20]}

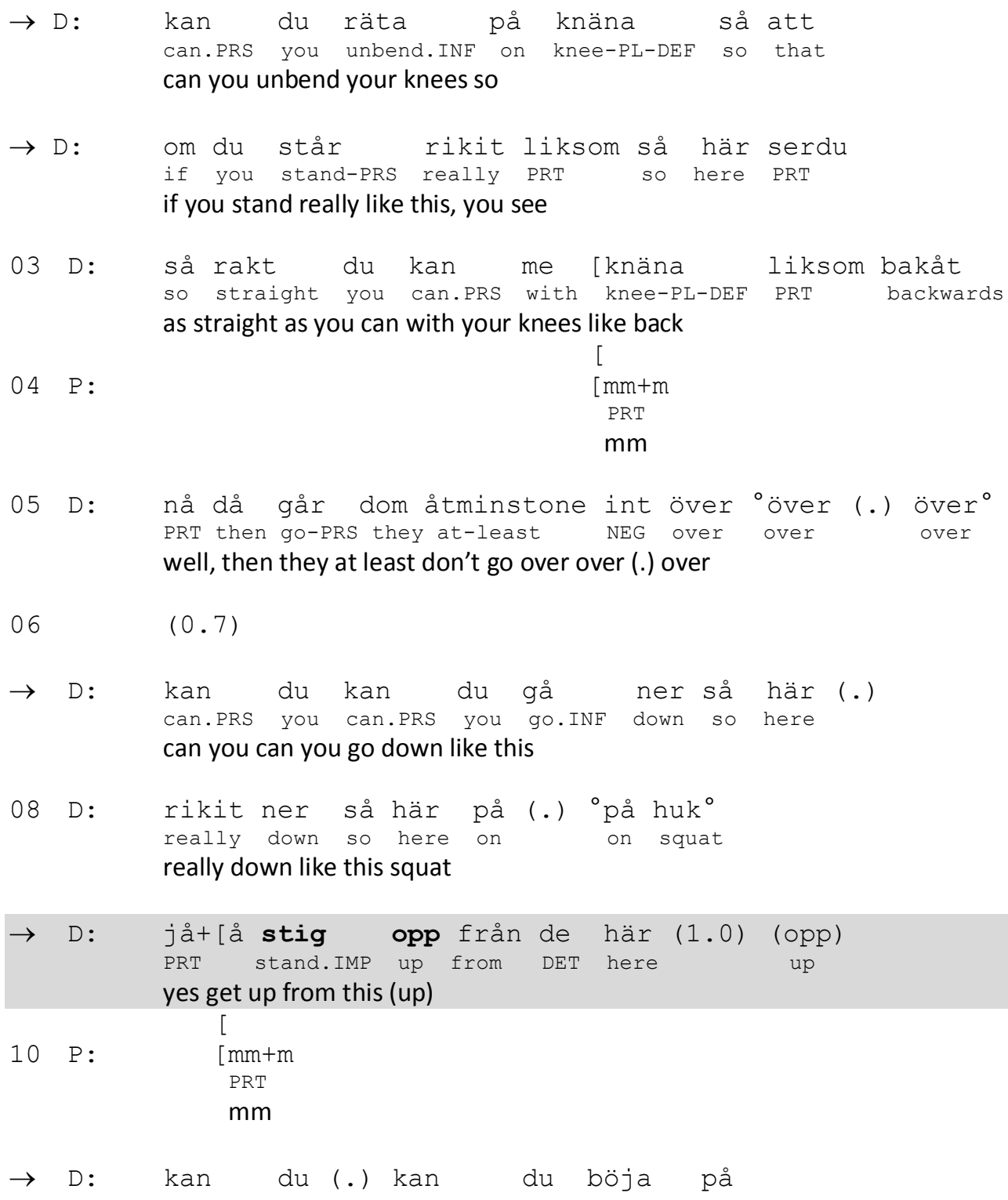




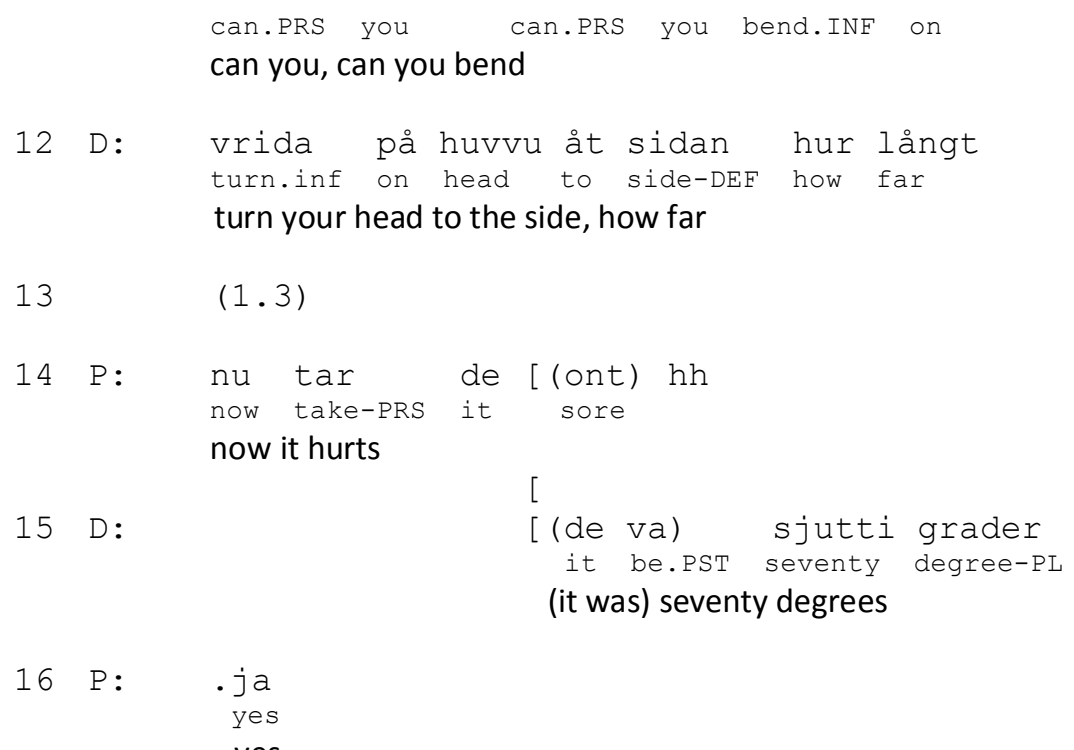

The doctor asks the patient to perform a series of physical actions, using both verbal and embodied resources while instructing the patient. In lines 13, the doctor uses a question format with the modal verb kan 'can' combined with a conditional om-clause, which specifies the nominated action (cf. Lindström, Lindholm, and Laury 2016 on conditionals as directives). In line 7, the doctor produces another interrogative directive initiated with kan. This directive is both verbal and embodied: the doctor asks the patient to squat at the same time as he performs the movement of sitting down in a crouching position with her knees bent. The acknowledgement token $j a ̊ a ̊$ 'yes' in line 9 is produced in response to the patient's squatting: the doctor displays that he has registered her movement. His following directive stig opp från de här 'get up from this [position]' is produced with the verb in the imperative, and it is accompanied by the doctor moving to an upright position (see Figure 1). 


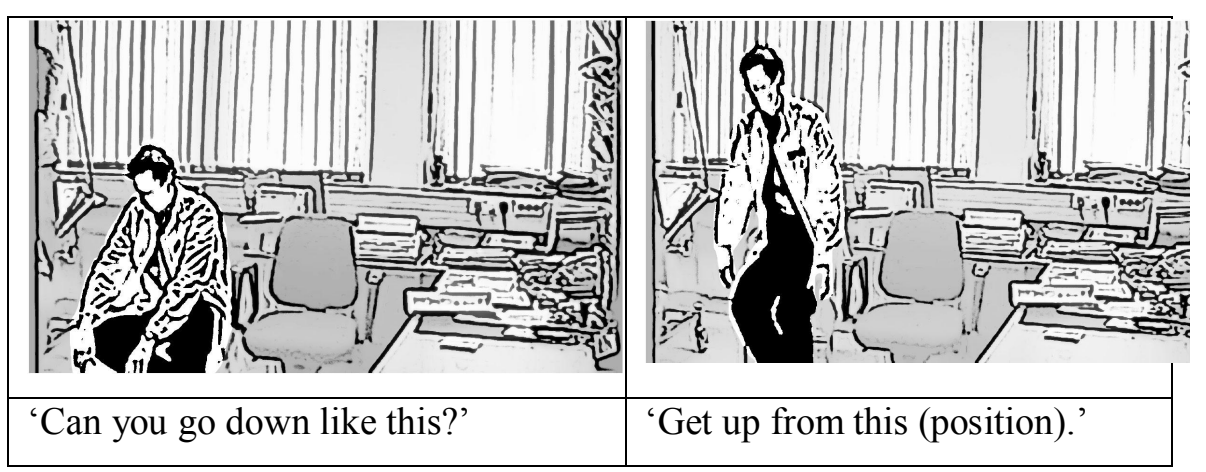

Figure 1. The doctor's bodily demonstrations in extract (2).

The doctor then proceeds to give the patient the directive to turn her head, again using a question format with kan 'can' (1. 11-12). Thus, the extract illustrates how a diagnostic activity, dealing with the actions of squatting and returning to an upright position, comes to an end. The interrogativemodal directives with kan 'can' focus on the patient's ability to perform physical tasks, whereas the imperative turn marks the releasing act: i.e. bending down is the actual test task while standing up is resuming the normal position, not necessarily a test of ability. When a new diagnostic phase, dealing with another part of the body, is initiated in lines 11-12, an interrogative-modal directive is used to launch a test again.

In extract (2) above, the imperative was included in a two-part directive sequence (getting down/getting up) and accompanied by a physical demonstration by the doctor. Extract (3) provides a parallel case. Here the doctor is examining the flexibility of the patient's hand. 


\section{(3) [S-SWE:LOP:6]}

01 D: den den (0.6) [håller sej s]till [där ja it it hold-PRS REFL still there yes it stays still there, yes

$02 \mathrm{P}:$

[ $\quad]$
[det håller $]$
it hold-PRs
it stays, it stays

03 still

still

still

04 D: ja.hh (.) å de de e ju ganska bra de va yes, and that is quite good, isn't it

05 för då minskar vär[ken men] .hh for then reduce-PRS pain-DEF but because then the ache is reduced

$06 \mathrm{P}:$

$\left[\begin{array}{ll}{[j a+a \quad]} \\ \text { PRT } \\ \text { yeah }\end{array}\right.$

07 $(0.3)$

$08 \mathrm{D}$ $\begin{array}{llll}\text { eh du (0.4) de } e & \text { samma sak [där] förstås } \\ \text { PRT you } & \text { it be.PRS same thing there of-course }\end{array}$ um, it is the same thing there of course

09 P :

yes $\rightarrow \quad$ D: $\quad \begin{array}{lllll}\text { får ja *se } & \text { dej< knyta } & \text { handen }>\text { oå såo }< \\ & \text { may-PRS I see.INF you.oBJ clench. INF hand-DEF and so }\end{array}$ may I see you clench your hand, so

( $(* D$ demonstrates with her hand $)$ )

$\rightarrow \quad \mathrm{D}:$

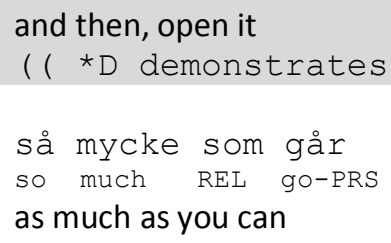
and it be.PRS det here REL NEG want.PRS really yet and it is this one that does not want to quite yet 
The patient is lying down on the examination table, and the doctor is performing a physical examination. When the doctor asks the patient to clench her hand (1. 10), she uses the interrogative format with a permissive modal: får ja se ‘may I see’ (cf. Ervin-Tripp 1976:29 on “permissive directives"). The doctor's directive is thus formatted as being for the benefit of herself; it is warranted by her diagnostic work (1. 1-8) that she needs to complete. The follow-up directive in line 11 is sequentially linked to the preceding one with the connectors $\stackrel{a}{s} \stackrel{a}{a}$ 'and then', which hearably initiate a new prosodic unit, and has the form of an imperative. ${ }^{5}$ As in (2), the directive with the imperative marks a releasing action, but it is also linked to diagnostic work as the opening of the hand should be done to a position beyond a relaxed position. When producing these two directives, the doctor simultaneously demonstrates the clenching of the hand and stretching out of fingers with her own hand (see Figure 2). The demonstration explicates what the patient is expected to do, but also what she should be able to do in a physically normal condition.

\footnotetext{
${ }^{5}$ In the transcription, it may look as if the object + infinitive construction of the first directive får ja se dej knyta handen continues to line 11, (fär ja se dej) räta ut den, in which case räta would be an infinitive form. This interpretation is not plausible, given the prosodic upstep at the beginning of line 11 and the connector $s a$ ' then' which is stressed, marking the start of a subsequent, releasing action; thus, the subsequent action is serially linked to the antecedent one but is formulated syntactically independent of it with a finite verb form (imperative). Compare this with extract (2) in which the subsequent, releasing directive is also in the imperative.
} 


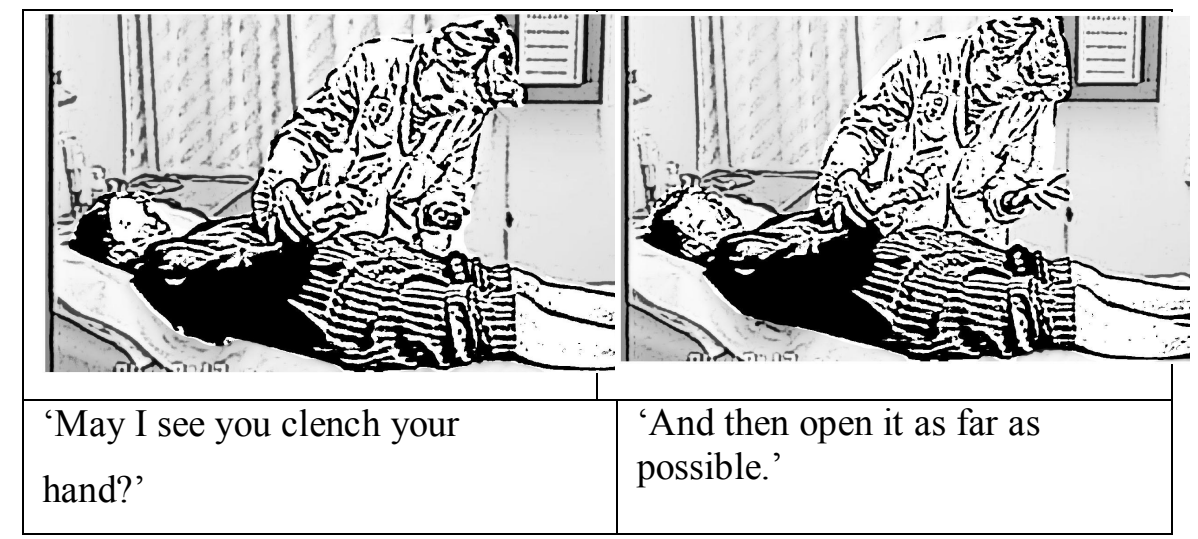

Figure 2. The doctor's bodily demonstrations in extract (3).

In line 14 , the doctor's directive is followed by an online commentary a de $e$ de här som inte vill riktit ännu 'and it's this one that doesn't want to quite yet' (Heritage and Stivers 1999), in which she evaluates what she is seeing during physical examination of the patient.

The exchange in extract (4) provides yet another illustration of a question directive followed by an imperative (1. 1-2), but, in addition, the doctor is initiating repair with the imperative.

(4) [S-SWE:LOP:10]

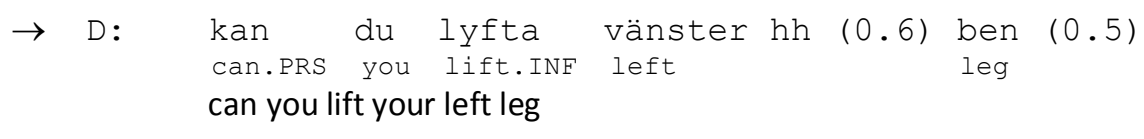

$\rightarrow \quad$ *upp allt eh >lyft de rakt<
up all PRT lift.IMP it straight
up all the way, uh, lift it straight
$\left(\left({ }^{\mathrm{P}}\right.\right.$ starts lifting the leg in a bent position $\left.)\right)$




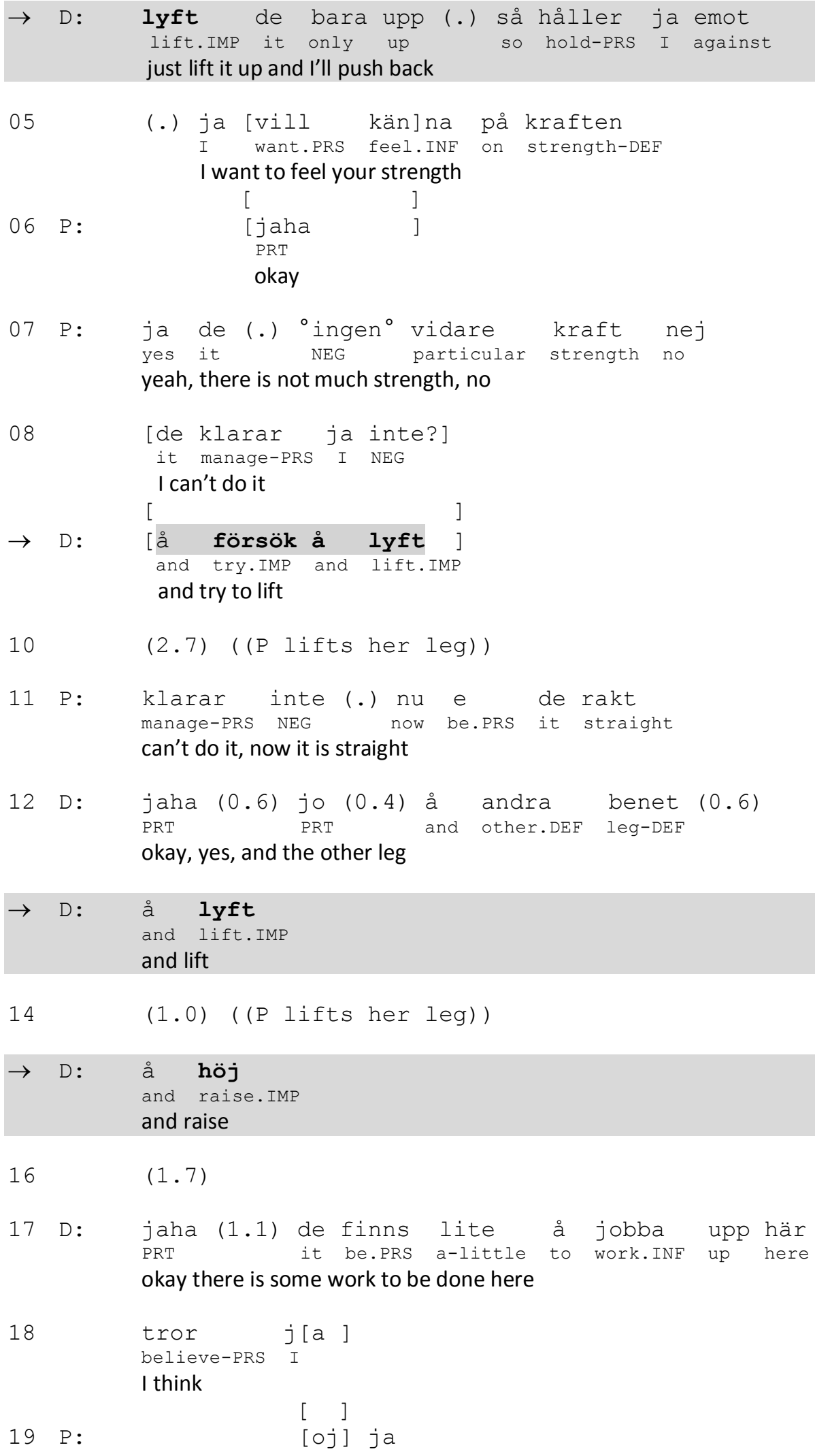


In extract 4 , the patient is lying down, and the doctor asks her to lift her left leg. The patient starts lifting her leg with her knee bent (1. 2). This is not a correct measure, and the doctor reacts to this by asking the patient to keep her leg straight while lifting it. The first directive in the series has the form of a question, thus initiating the diagnostic work and orienting to possible contingencies related to the patient's ability to perform the nominated action, similar to the cases in (2) and (3). The correcting directive action in line 2 is expressed with an imperative, thus only focusing on what the patient should do and not on the question of her ability to perform the action. This directive is, however, followed by the patient putting her leg down instead (1. 3). The doctor proceeds by formulating a further directive in the imperative accompanied by the adverb bara 'just, simply', followed by an account of what she will do in conjunction with the patient's action (1. 4-5). The second imperative (lyft de bara upp 'just lift it up') thus functions as a go-ahead, a response to the patient's attempted but not completed action - a function which is accentuated with the adverb bara (see section 5). The doctor's further account in line 5, ja vill känna på kraften 'I want to feel your strength', motivates the requested action as part of the diagnostic work. In line 9 , as a response to the lack of action from the patient, the doctor once more repeats the directive, this time in the form of a coordinated imperative 
verb chain (försök å lyft 'try and lift'), in which the verb försök 'try' functions as an encouraging prompt.

When moving on to the examination of the patient's other leg (1. 1213), the directives are expressed in a short and direct manner with a conjoined series of imperatives: å andra benet, å lyft, å höj 'and the other leg, and lift, and raise'. Hence, this usage further highlights the principle where non-modulated imperative turns are treated as unproblematic in a latter part of an on-going diagnostic activity, i.e. when a coherent chain of actions is established and unfolding in real time (see Raevaara this volume).

Extracts (2-4) above also demonstrate the situatedness of directive turns and their embedding in practical, embodied activities, where the human body is the target of directive actions as well as a resource in communicating them by demonstrating the nominated action. In the next section we account for imperative turns in other activities than the physical examination; these are different kinds of routinized activity contexts, and the imperative turns tend to be modified with mitigating or softening verbal elements.

\section{Modulated imperative turns: projected routine actions}

As the quantitative overview in section 3 showed, a considerable number of imperative turns are modulated by different means (see Table 1). In section 4 we analyzed uses occurring during the physical examination, in which the 
imperative turns were typically non-modulated. In the following we turn to cases in which the imperative turns contain mitigating formulae or particles. These cases occur in routinized activities during the medical consultations. We focus on the common social formula varsågod 'please', lit. 'be so good' - which in itself incorporates a lexicalized imperative of the verb 'to be' (var) - and the most frequent modifying adverbs/particles in the data: lite 'a little, a bit', bara 'just, simply' and $n u$ 'just, (now)' - all of which have a general restricting or diminutive meaning in common. Modulated imperative turns typically appear at the opening of the consultation when the doctor invites the patient to come in or to sit down. They also occur in transitional actions that mark either the beginning or the end of the examination phase.

The initial phase of welcoming routines in which the doctor establishes a relationship with the patient, is followed by a phase in which the doctor finds out about the reason for the patient's visit. In our data, the transition from the initial routines to the anamnesis (for a detailed account of doctors' opening questions, cf. Ruusuvuori 2000) is typically initiated by a directive including the verb berätta 'tell' in the imperative form combined with the particle lite 'a little, a bit'. The following extract (5) illustrates the use of this format (1. 10) in a slightly different context later in the consultation.

(5) [F-SWE:INK:13] 


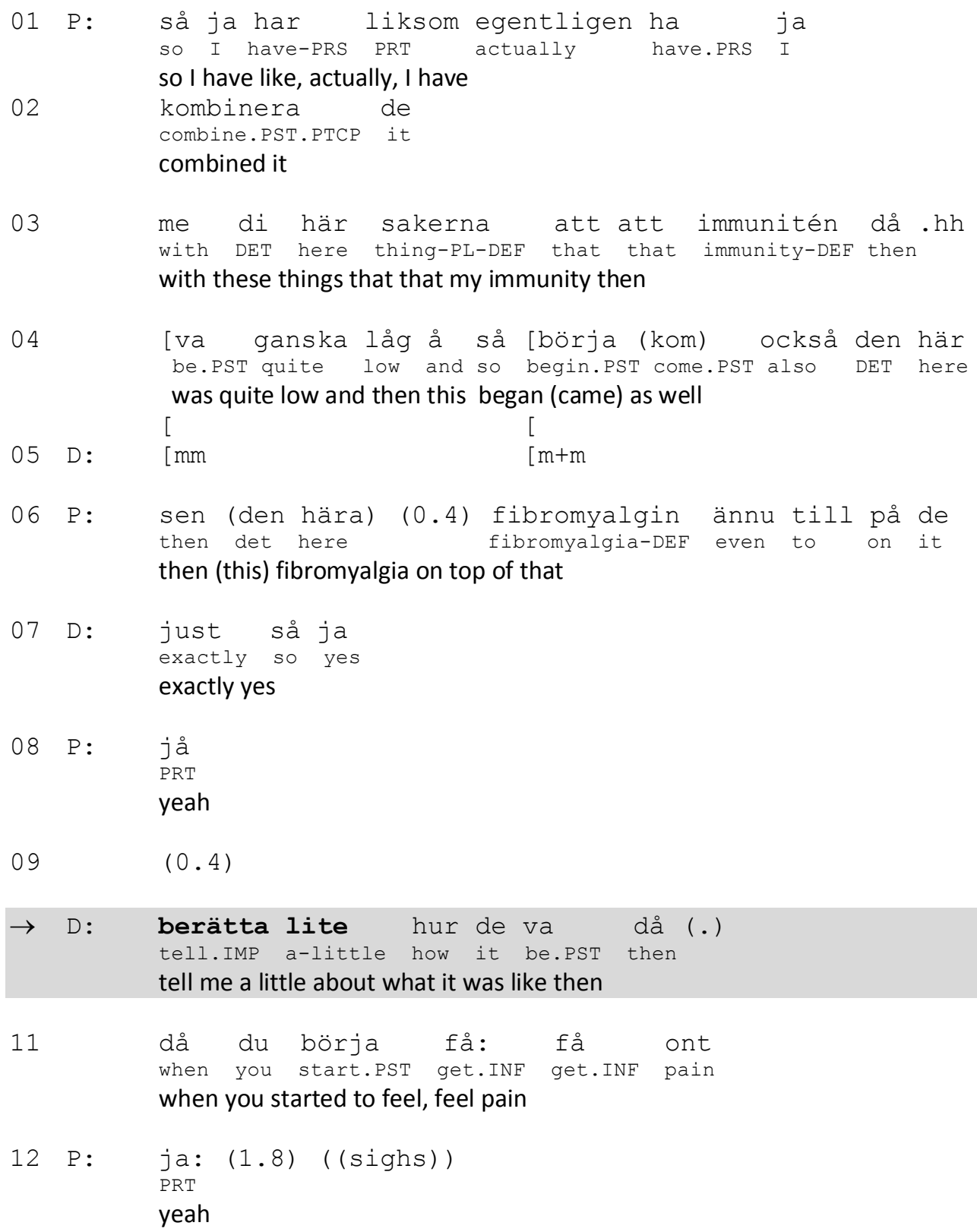

The doctor's introduction into the anamnesis in this consultation (not shown in the extract above) had the form of a proposal, involving both the verb berätta 'tell' in present indicative and the modifier lite: ska vi börja me om du berättar lite om hur du har de nuförtiden 'shall we start with if you tell 


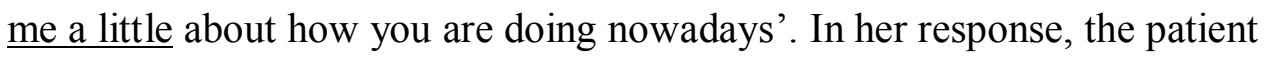
provided a lengthy narrative account of her medical history, stretching from the onset of various symptoms connected with a possible diagnosis of mercury poisoning to the presentation of pain. In lines $1-6$ in extract (5), the patient suggests a connection between the state of her immune system and the onset of fibromyalgia. As discussed by Ruusuvuori (2000:164-171), patients can make diagnostic suggestions in attempts to close the problem presentation and pass the turn back to the doctor. In this case, the doctor first reacts with the next turn just så ja 'right, yes' (1. 7), which marks her recipient position. The berätta-initiated directive in line 10-11 then suggests a shift forward in the conversation (cf. Ruusuvuori 2000:197-236 on how patients' problem presentations are received by doctors). The adverb lite 'a little, a bit' is recurrent in the doctors' opening and forward shifting routine directives in the data. Its basic diminutive meaning serves to mitigate the directive move (cf. Wirdenäs and Norrby 2001 on lite as a hedging particle; see also Bolden on Russian, this volume): a full account is not expected, especially as the patients' histories may be complicated and delicate as in (5).

Extract (6) illustrates an imperative turn rounding off a diagnostic activity. The doctor signals the end of the examination of the patient's lungs verbally by a stand-alone, activity-closing så 'so’ (Ottesjö and Lindström 2005) simultaneously removing the stethoscope and placing it in her pocket (1. 4). Shortly thereafter, when the doctor has sat down at her desk, she 
invites the patient to get dressed using an imperative turn modulated by varsågod 'please': varsego ta på skjortan igen 'please put your shirt on again', 1.16 and 18. While producing the turn she hands the patient her shirt (1. 18). Together these verbal and physical actions indicate the transition out of the examination phase and subsequently, after a brief pause, the doctor initiates talk about future appointments (1. 22-23).

(6) [S-SWE 9:LOP:9] ((9 s. D listens with a stethoscope))

02 D: så $\quad$ so $(0.6)$ å andas djupt in å ut. so (0.6) and take a deep breath in and out ((14.0 s. P breathes heavily while D examines))

04 D: $\quad \begin{aligned} & \text { så. ( ( } \\ & \text { PRT }\end{aligned}$

so

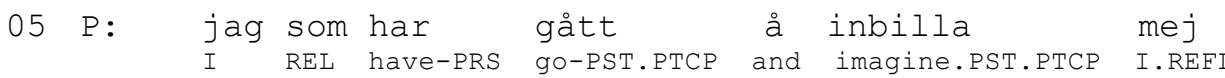
and I have been imagining

$06 \quad \begin{array}{ll}\text { att ja } & e \\ \text { that } & \text { riktit }\end{array}$ that I was quite

$07 \quad(0.3)$

$08 \mathrm{D}: \mathrm{Va}$

PRT

what

$09 \quad(0.5)$

10 P: riktit skapli $(0.7)$ à $s[e n e$ ] de inga bra really tolerable and then be.PRS it NEG.PL good quite tolerable (0.7) and then it's no good

11 D :

[.jaha $]$ PRT I see 


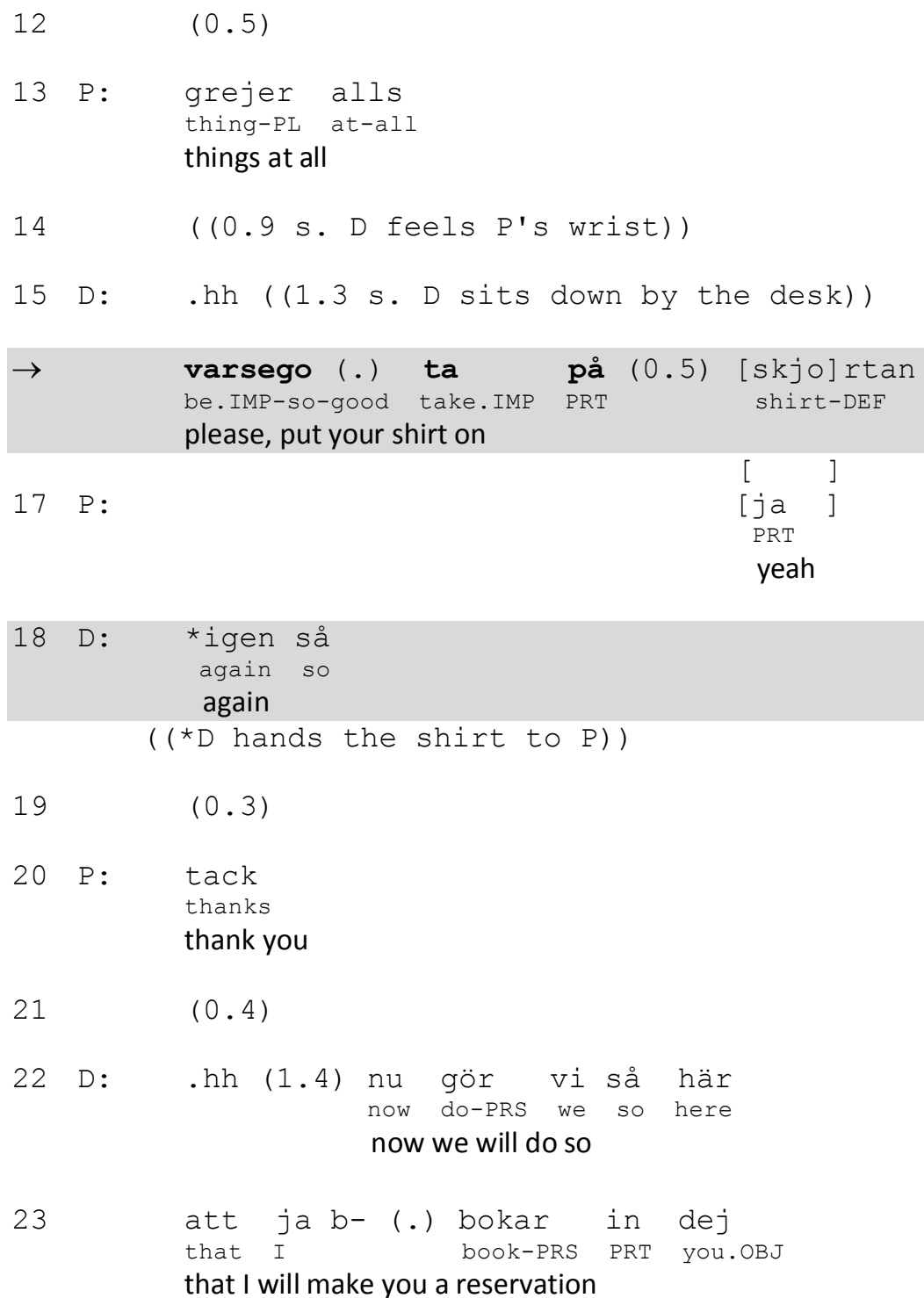

The imperative turn responds to the patient's expectation that the conventional next step after a concluded examination is to get dressed. The expression varsågod ta på skjortan igen 'please, put your shirt on again' thus functions as a go-ahead, rendering the imperative a tone of a routine social offer (i.e. as if granting a wish from the patient to get dressed again). 
The formula varsågod also co-occurs with other modulating elements, like the restricting adverb bara 'just, only'. Bara generally renders the directive action a permissive tone, implying that the directive is a response to some kind of initiative (an attempt or wish to do something) by the requestee (Hellberg 1990; Teleman et al. 1999:717; cf. also Steensig and Heinemann on bare in Danish, this volume); compare extract (4) above in which bara with an imperative responded to an attempted but failed action. Modifications of this kind typically occur during opening routines when the patient is asked to come into the consultation room and to take a seat. They also occur at the beginning or the end of the examination when the patient should take off or put his or her clothes on. The directives in these cases respond to the patient's expectations of the routine course of a physical examination which at certain points make certain actions relevant; in other words, the modulated directive seems to project an upcoming attempt from the patient's side, for example, to sit down or get dressed again.

In extract (7), bara postmodifies an imperative turn already modulated with the formula varsågod, alluding to an offer as in (6) above. The doctor has just concluded the physical examination and now asks the patient to come away (kom bort) from the examination table and put on her clothes (1.9), the latter directive (1. 13) expressed with an unintegrated conditional clause (Lindström et al. 2016). 
(7) [F-SWE 15:INK:15]

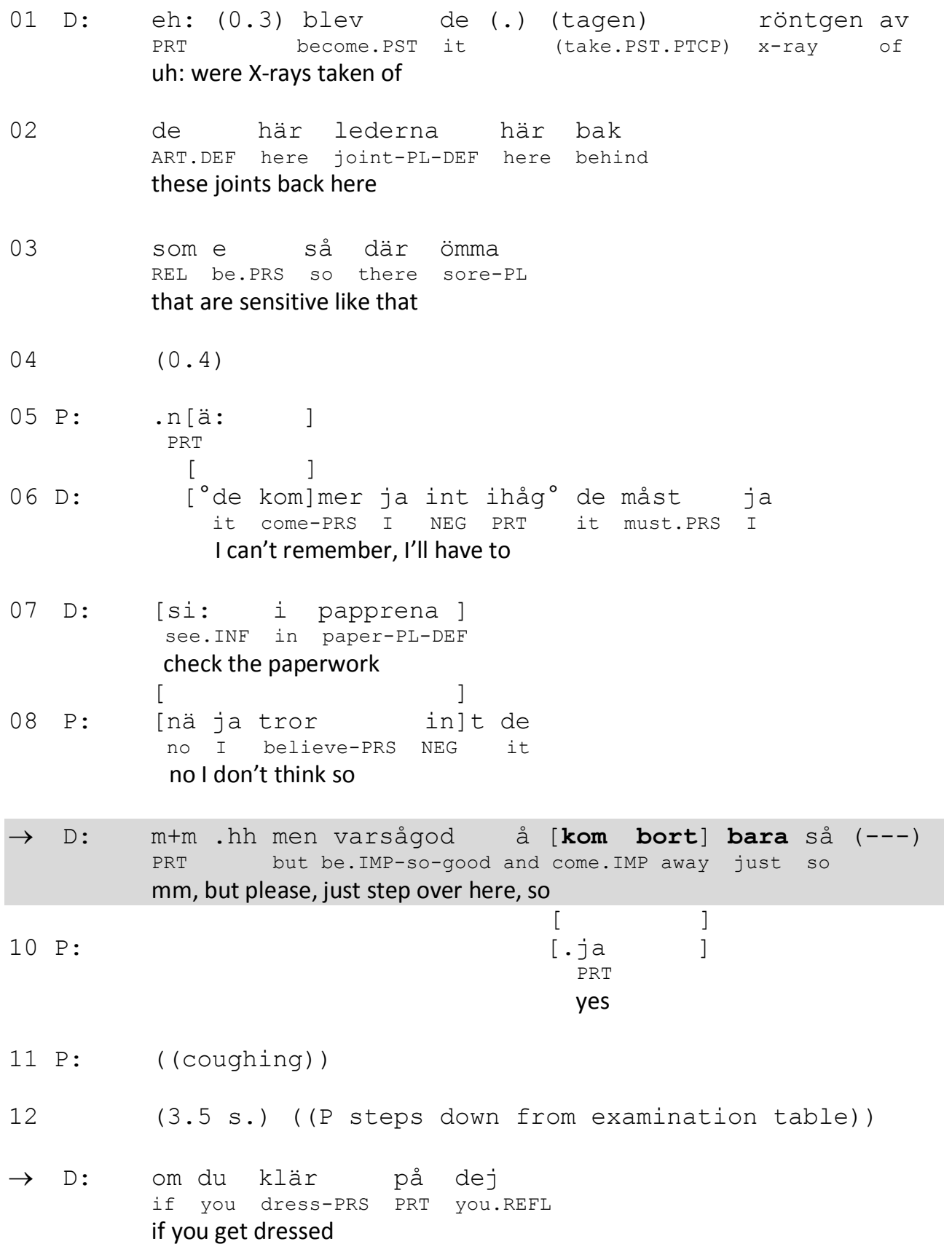

Here, the permissive bara with the imperative responds to the projected conclusion of the physical examination which leaves the patient prepared to get down from the examination table and get dressed. 
Bara can also premodify the imperative, thus giving the requested action extra focus; that is, the imperative follows the particle and is intimately within its scope in the sense of 'nothing but x' (see Heinemann and Steensig this volume). This usage is illustrated by extract (8) in which the doctor prepares to measure the patient's blood pressure. The patient is lying still on the examination table while the doctor increases the pressure in the blood pressure monitor. At this point, he tells the patient "just to relax", bara slappa av (1. 2). Clearly, this is not granting permission to act in a certain way, but is a recommendation on to act in an uncomplicated manner: the patient should focus on being relaxed (and nothing else) as relaxation contributes to more normal values.

\section{(8) [S-SWE:LOP:5]}

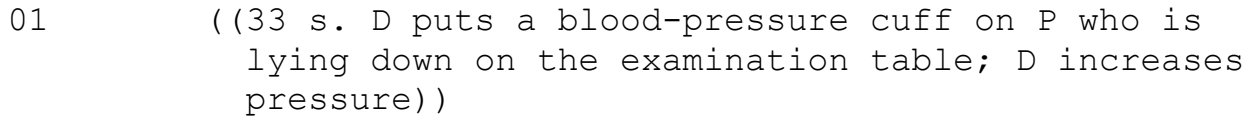

03 ((40 s. D measures P:s blood pressure))

As we have noted above, non-modulated imperative turns tend to be embedded in a diagnostic activity during the verbal/physical examination where the patient's ability to perform certain motions is tested (and usually initially introduced with interrogative directives with modal kan $d u$ 'can you'. Extract (8) also shows an imperative turn from the physical 
examination, but with a modifying element. We argue that the modification has to do with the routine directive action with the aim to calm down the patient. In other words, the imperative turn does not request an action to test something, but aims to produce felicitous conditions for diagnostic work.

Quite a few imperative turns occur outside of the diagnostic work, either at the beginning of the consultation or towards the closing when treatment is discussed. This is the case especially in the data from Finland, where such imperative turns are typically modulated by the adverb/particle $n u$ 'now, just'. The source of this discourse particle is the temporal adverb $n u$, but it has developed a variety of textual and pragmatic meanings (see Saari and Lehti-Eklund 2016). As noted by Hakulinen and Saari (1995), nu may occur in utterances which are subsidiary to the main action. An example of such usage is seen in extract (9) in which the doctor and the patient enter the consultation room, walking towards the doctor's desk. At this point, the doctor in a routine manner asks the patient to sit down, using the reflexive verb slå er ner 'have a seat' combined with the particle $n u$ (l. 1). This utterance is produced in a prosodically subdued manner, the doctor still being behind the patient's back. Having reached his desk, he then quickly continues on to comment on a previous appointment, referring to the patient's files, which is a move towards the core activity in the consultation.

(9) [F-SWE:INK:19] 


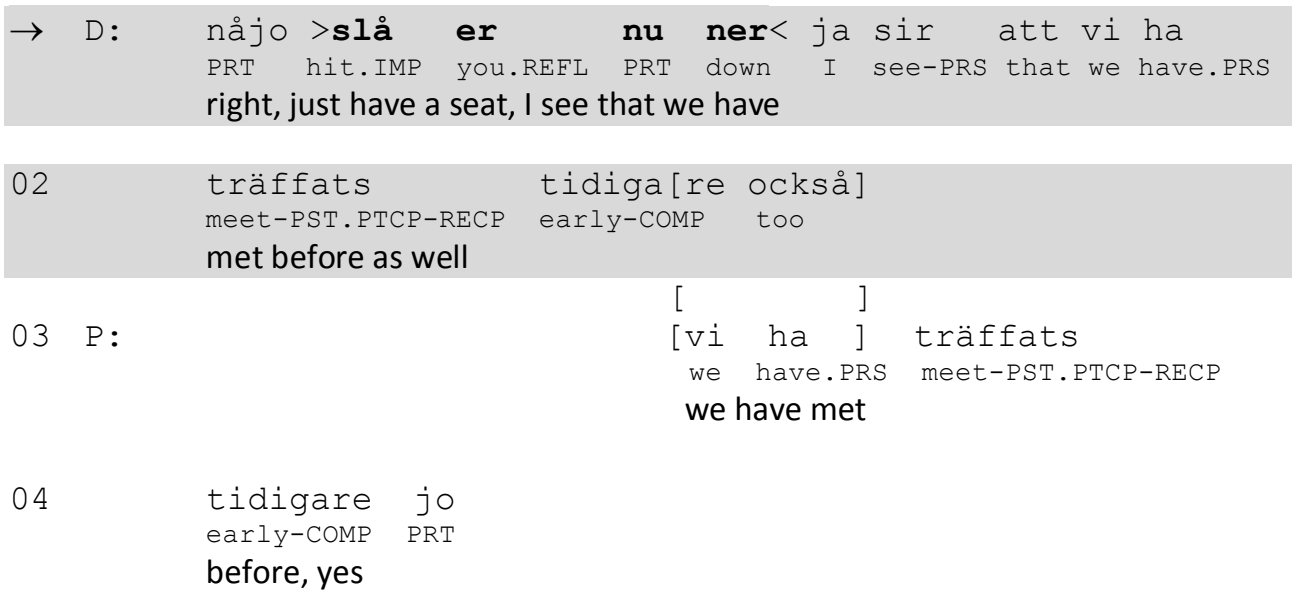

Extract (10) provides an example from the closing phase of the consultation.

In line 1 , the doctor gives the patient some documents relevant for the treatment, and in line 3, he tells the patient to call him (ring mej) if her muscular tightness continues, using an imperative with $n u$.

(10) [F-SWE:INK:2]

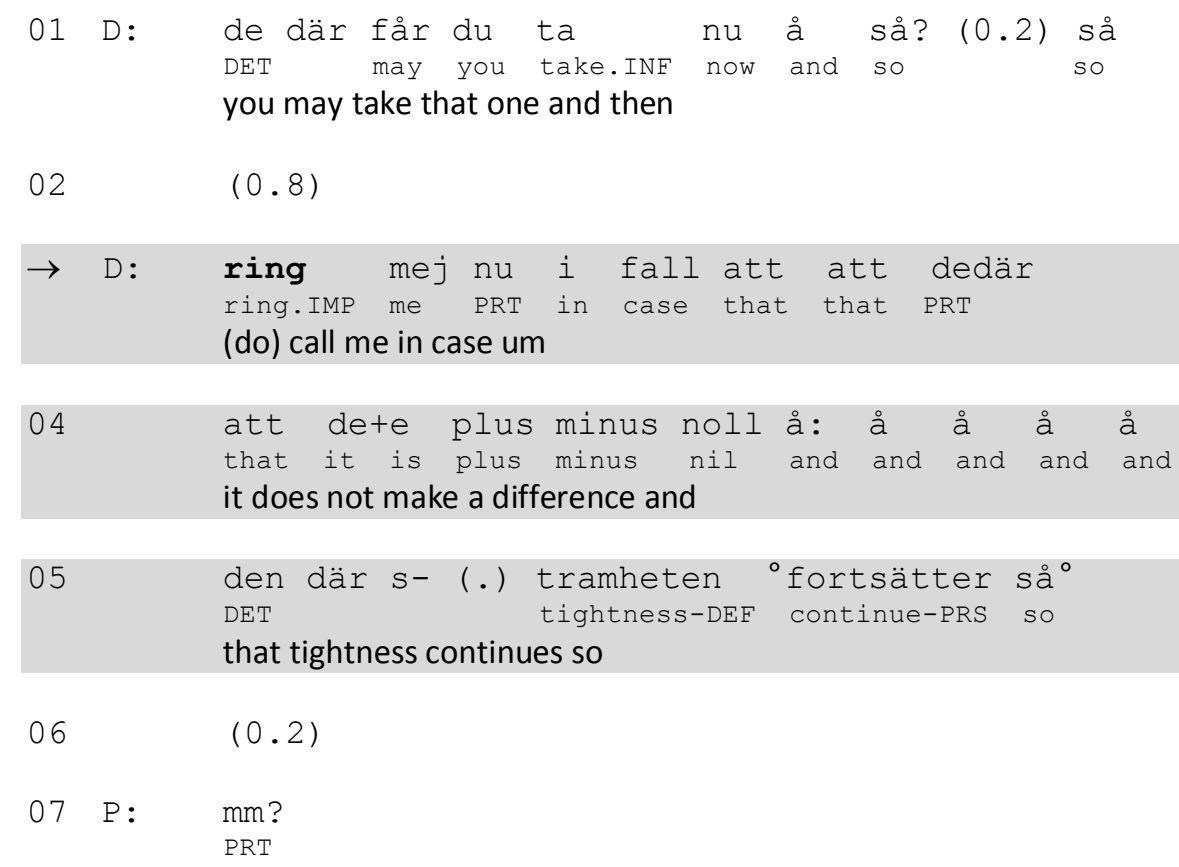




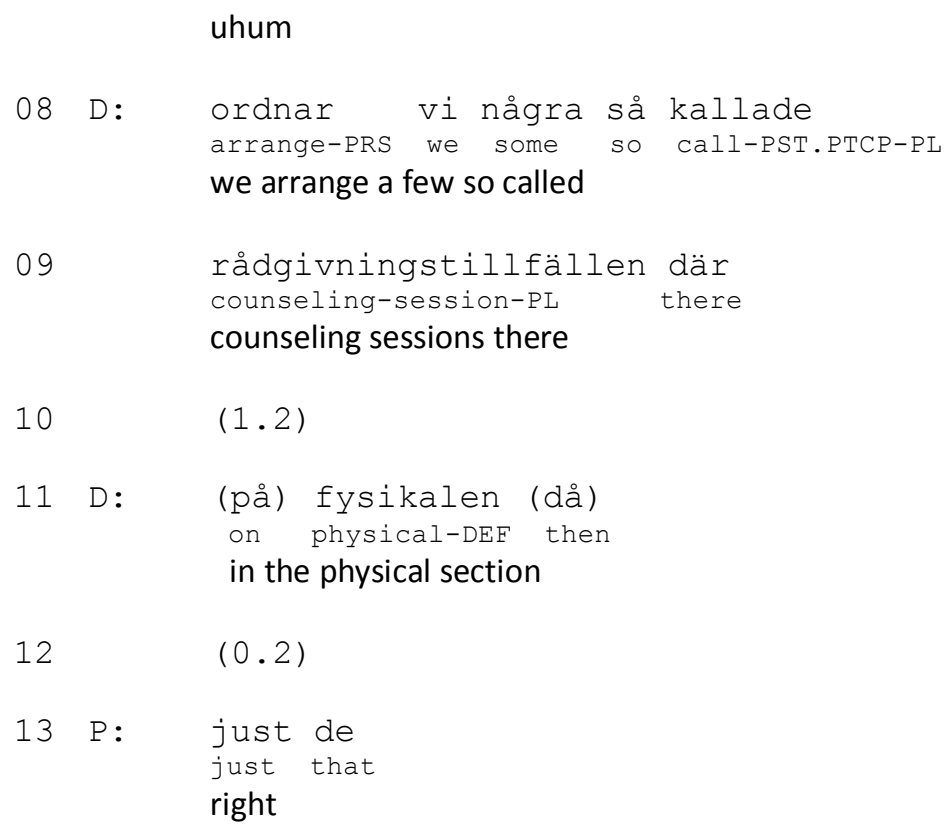

As in (9), the imperative turn occurs outside of diagnostic work. It formulates a routine recommendation, responding to possibly locally arisen expectations from the patient about the future course of the treatment process. Sensitivity to local, albeit routine, contingencies probably motivates the use of the originally temporal $n u$ in contexts like in (9) and (10).

As noted in section 3, there is a considerable difference between the Sweden-Swedish and Finland-Swedish datasets with regard to the frequency and use of imperatives with a modifying particle. The most prevalent modifiers in the Finland-Swedish imperatives were $n u$ with 9 occurrences, and lite and bara with five occurrences each, whereas the Sweden-Swedish data contained two occurrences of lite 'a little, a bit' and bara 'just, simply', and only one of $n u$ 'just (now)'. $N u$ makes the greatest difference here, since 
its use in Sweden Swedish is constrained to certain parenthetical expressions (like vänta $n u$ 'wait now'), whereas it is a productive discourse particle in Finland Swedish, probably influenced by the use of the temporal adverb nyt 'now' as a discourse particle in Finnish (Hakulinen and Saari 1995, Saari and Lehti-Eklund 2016).

In the Finland-Swedish consultations the use of the particles is especially frequent in the opening and closing phases in which the doctor does different kinds of invitational work, such as welcoming, offering a seat, inviting a narrative, and offering opportunities for future appointments. These actions have a routine character, and the positions for performing them are easily projected by the patients. It could be argued, then, that the modulating work performed with colloquial discourse particles coheres with the casual dimension of these mundane activity contexts which are subsidiary to the core diagnostic work.

Although there are fewer particles attached to the imperatives in the Sweden-Swedish consultation openings, there are other means for communicating a casual, mundane tone. We notice especially the use of declarative and interrogative formatted directives instead of imperatives (e.g. kan du berätta 'can you tell?'). In addition, the doctor often invites the patient to give an account of her ailments through the use of mundane phrases, like hur mår du 'how are you', hur står det till 'how are you doing?' instead of the imperative and particle combination berätta lite 'tell (me) a bit'. These differences between the two varieties suggest that Finland 
Swedish and Sweden Swedish favor slightly different means for communicating the same interactional meaning.

However, common to both varieties is the use of non-modulated imperatives during the physical examination phase. These occur in an environment where they are embedded in on-going diagnostic work, typically in subsequent directives in a series of diagnostic acts which initially have been launched with a modal question directive orienting to the patient's ability to perform a task. The imperative is then often found in a releasing, back-to-normal-position directive which concludes the series of diagnostic directives. Another way of putting it is to say that imperatives feature in activities where the participants work together towards a common goal to find out what is wrong with the patient (cf. Rossi 2012 on imperatives during joint action). Such common orientation is most salient in cases where the action expressed by the imperative is performed jointly by the doctor and the patient - especially when the doctor physically demonstrates the action that the patient should perform.

\section{Conclusion}

This chapter has explored the use of imperatives in an institutional setting, namely doctor-patient consultations in Swedish in Sweden and Finland. Imperatives occur in the openings and closings of the consultations as well 
as during the verbal and physical examination. The uses in the openings have to do with welcoming routines, such as the doctor offering the patient a seat, and in the transition to the medical history when the patient is asked to tell about his or her symptoms. Imperatives in closings (or in episodes approaching closings) refer to future actions concerning, for example, the dosing of a medicine or when to call the doctor again for a future appointment. These imperative turns contain modifying elements, like conventional social formula of the type varsågod 'please' or different mitigating particles. Given their typical context of occurrence, these modifications seem to orient to the routine nature of the directive actions. What will happen in the opening or closing is socially conventional and easy to project for both conversational participants; thus, the modulating elements cohere with the mundane and familiar character of the nominated actions.

The use of imperatives follows a different pattern in the physical examination phase. These imperatives have an immediate and indexical relation to the on-going activity and most often they do not contain modulating elements. However, directives in the form of an imperative are not typically produced as the first move in a diagnostic activity, but are embedded in subsequent moves within diagnostic work. In other words, a typical trajectory for directives in a physical examination is: 1) the doctor launches a diagnostic activity with a declarative or interrogative directive containing the modal kan 'can', which orients to test the patient's physical 
ability; 2) subsequent, and possibly more projectable, steps in diagnostic work incorporate imperative directives - typically as a closing move which ends the testing, but does not necessarily include testing in itself (for example, when the patient is asked to resume normal position). Some modulated imperatives may also occur during the examination. In these cases they seem to be produced in response to the other participant's (possibly failed) actions, rendering the directive turn a tone of permission or go-ahead. In general, then, modulated imperative turns have a link to projectable actions, which are possible to foresee because they already have been attempted or are routinized.

Our data represent the two national varieties of Swedish. Although the grammatical formatting of imperatives or other directive formats does not differ between Sweden Swedish and Finland Swedish, there is some variation in the frequency, distribution and pragmatic framing of actions using the imperative. We found that imperative turns are modulated with a particle more often in the data from Finland than the data from Sweden, and especially this is the case during the opening and closing phases. It seems that the interactional value of these particles in Finland Swedish is to communicate a prosocial, casual tone in routine actions, like when offering a seat or inviting a narrative. The data suggest that the Sweden Swedish doctors utilize other means to reach the same effect in the same activity contexts by using, for example, expressions of the type 'How are you?'. 
Hence, there is a difference in strategies for achieving the same interactional goal but not a difference in interpersonal orientation.

\section{Acknowledgements}

We thank Ulla Melander Marttala for granting us permission to use the Swedish corpus LOP and our research assistants Katja Koskinen, Outi

Nieminen and Emmi Toivio for their valuable help in retrieving and preparing the extracts analyzed in this study.

\section{References}

Byrne, Partick S., and Barrie E. L. Long. 1976. Doctors Talking to Patients. A Study of the Verbal Behaviour of General Practitioners Consulting in Their Surgeries. London: Dept. of Health and Social Security.

Clyne, Michael. 1992. "Pluricentric Languages - Introduction". In Pluricentric Languages, ed. by Michael Clyne, 1-9. Berlin: Mouton de Gruyter.

Drew, Paul, and John Heritage. 1992. "Introduction". In Talk at Work: Interaction in Institutional Settings, ed. by Paul Drew, and John Heritage, 3-65. Cambridge: Cambridge University Press.

Ervin-Tripp, Susan. 1976. "'Is Sybil there?' The Structure of Some American English Directives." Language in Society 5: 25-66.

Hakulinen, Auli, and Mirja Saari. 1995. "Temporaalisesta adverbista diskurssipartikkeliksi [From a temporal adverb to a discourse particle]." Virittäjä 4: 481-500.

Hellberg, Staffan. 1990. "Uppmaningarnas syntax och direktiva satsers 
betydelse [On the syntax of directives and the meaning of directive clauses]." In Svenskans beskrivning 17, ed. by Erik Andersson, and Marketta Sundman, 21-37. Åbo: Åbo Akademis förlag.

Heritage, John, and Maynard, Douglas, W. (eds). 2006. Communication in Medical Care. Interaction Between Primary Care Physicians and Patients. Studies in Interactional Sociolinguistics 20. Cambridge: Cambridge University Press.

Heritage, John, and Stivers, Tanya. 1999. "Online Commentary in Acute Medical Visits: A Method of Shaping Patient Expectations.” Social Science \& Medicine 49: 1501-1517.

Keevallik, Leelo. 2003. From Interaction to Grammar. Estonian Finite Verb Forms in Conversation. Uppsala: Acta Universitatis Upsaliensis.

Lindholm, Camilla. 2003. Frågor $i$ praktiken. Flerledade frågeturer $i$ läkare-patientsamtal [Questions in practice. Multi-unit question turns in doctor-patient interaction]. Helsinki: Svenska litteratursällskapet i Finland.

Lindström, Anna. 2005. "Language as Social Action. A Study of How Senior Citizens Request Assistance with Practical Tasks in the Swedish Home Help Service." In Syntax and Lexis in Conversation. Studies on the Use of Linguistic Resources in Talk-in-interaction, ed. by Auli Hakulinen, and Margret Selting, 209-230. Amsterdam: Benjamins.

Lindström, Jan, Camilla Lindholm, and Ritva Laury. 2016. "The Interactional Emergence of Conditional Clauses as Directives: Constructions, Trajectories and Sequences of Actions." Language Sciences. doi:10.1016/j.langsci.2016.02.008.

Linell, Per. 2009. Rethinking Language, Mind, and World Dialogically. Interactional and Contextual Theories of Human Sense-making. Charlotte, NC: Information Age Publishing.

Linell, Per. 2011. Samtalskulturer. Kommunikativa verksamhetstyper $i$ samhället [Conversation cultures. Communicative activity types in society]. Linköping: Linköping University.

Melander Marttala, Ulla. 1995. Innehåll och perspektiv i läkarepatientsamtal. En språklig och samtalsanalytisk undersökning [Content and perspective in doctor-patient conversations. A linguistic and conversation analytic investigation]. Uppsala: Uppsala University. http://urn.kb.se/resolve?urn=urn:nbn:se:uu:diva-179654

Mishler, Elliott G. 1984. The Discourse of Medicine: Dialectics of Medical Interviews. Norwood, NJ: Ablex.

Norrby, Catrin, Camilla Wide, Jan Lindström, and Jenny Nilsson. 2015 a. "Interpersonal Relationships in Medical Consultations. Comparing Sweden Swedish and Finland Swedish Address Practices." Journal of Pragmatics 84: 121-138.

Norrby, Catrin, Camilla Wide, Jenny Nilsson, and Jan Lindström. 2015 b. 
"Address and Interpersonal Relationships in Finland-Swedish and Sweden-Swedish Service Encounters." In Address Practice as Social Action. European Perspectives, ed. by Catrin Norrby, and Camilla Wide, 75-96. Basingstoke: Palgrave Macmillan.

Ottesjö, Cajsa, and Jan Lindström. 2005. "Så som diskursmarkör [Så as a discourse marker]." Språk och stil 15: 85-127.

Reuter, Mikael. 1992. "Swedish as a Pluricentric Language." In Pluricentric Languages. Different Norms in Different Nations, ed. by Michael Clyne, 101-116. Berlin/New York: Mouton de Gruyter.

Rossi, Giovanni. 2012. "Bilateral and Unilateral requests: The Use of Imperatives and Mi X? Interrogatives in Italian." Discourse Processes 49: 426-458.

Rothstein, Björn. 2010. "Mood in Swedish." In Mood in the Languages of Europe, ed. by Björn Rothstein, and Rolf Thieroff, 71-84. Amsterdam: Benjamins.

Ruusuvuori, Johanna. 2000. Control in the Medical Consultation. Practices of Giving and Receiving the Reason for the Visit in Primary Health Care. Acta Electronica Universitatis Tamperensis 16. Tampere: University of Tampere.

Saari, Mirja. 1995. “'Jo, nu kunde vi festa nog'. Synpunkter på svenskt språkbruk i Sverige och Finland [On the use of Swedish language in Sweden and Finland]." Folkmålsstudier 36: 75-108.

Saari, Mirja, and Hanna Lehti-Eklund. 2016. "The Swedish Nu. A Historical Perspective." In "Nu" and "Na": A Family of Discourse Markers Across the Languages of Europe and Beyond, ed. by Peter Auer, and Yael Maschler. Berlin: de Gruyter.

Statistics Finland. 2015. Population Structure 2014. Helsinki: Statistics Finland. http://www.stat.fi/til/vaerak/2014/vaerak_2014_2015-0327 tie 001 en.html.

Statistics Sweden 2015. Population Statistics. Statistics Sweden, Stockholm. http://www.scb.se/en_/Finding-statistics/ Statistics-by-subjectarea/Population/Population-composition/Population-statistics/

Stivers, Tanya, Lorenza Mondada, and Jakob Steensig. 2011. "Knowledge, Morality and Affiliation in Social Interaction." In The Morality of Knowledge in Conversation, ed. by Tanya Stivers, Lorenza Mondada, and Jakob Steensig, 3-26. Cambridge: Cambridge University Press.

Teleman, Ulf, Staffan Hellberg, and Erik Andersson, 1999. Svenska Akademiens grammatik. Vol. 4. Stockholm: Svenska Akademien.

Wide, Camilla, and Benjamin Lyngfelt. 2009. "Svenskan i Finland, grammatiken och konstruktionerna" [Swedish in Finland, the grammar and the constructions]. In Konstruktioner i finlandssvensk syntax. Skriftspråk, samtal och dialekter, ed. by Camilla Wide, and Benjamin Lyngfelt, 11-43. Helsinki: Svenska litteratursällskapet i Finland.

Wirdenäs, Karolina, and Catrin Norrby. 2001. "En diskurspartikel 
vardande? Lite om lite [A discourse particle in the making? A bit about a bit]." Språk \& stil 11: 211-234. 